(C) 2015

Компанієць В. О., кандидат економічних наук,

Солодушко М. М., кандидат сільськогосподарських наук,

Кулик А. О., головний фахівець лабораторії економічних та маркетингових досліджень

ДУ Інститут сільського господарства степової зони НААН України

\title{
ЕКОНОМІЧНА ЕФЕКТИВНІСТЬ ВИРОЩУВАННЯ СУЧАСНИХ СОРТІВ ПШЕНИЦІ ОЗИМОЇ В УМОВАХ ПІВНІЧНОГО СТЕПУ УКРАЇНИ
}

\section{Рецензент - доктор сільськогосподарських наук Ю. І. Ткаліч}

Здійснено економічну оцінку результатів експериментальних досліджень з визначення продуктивності та особливостей виромування сучасних сортів пшениці м'якої озимої вітчизняної та зарубіжної селекиії. Дослідження проводилися на базі Синельниківської СДС Інституту сільського господарства степової зони НААН. Визначено сорти, щз характеризуються високою продуктивністю та стійкістю до несприятливої дії біотичних та абіотичних чинників середовища. Сформульовано рекомендації щзодо підвищення економічної ефективності виробництва зерна пшениці озимої на основі добору конкурентоспроможних сортів з високим врожайним та адаптивним потениіалом.

Ключові слова: пшениця озима, сорти, урожайність, собівартість, чистий дохід, рентабельність.

Постановка проблеми. Вивчення поточної ситуації, що склалася в зерновій галузі, свідчить, що на сьогодні потребує вирішення проблема забезпечення сталості виробництва продовольчого зерна пшениці високої якості, підвищення його конкурентоспроможності та прибутковості.

3 досліджень наукових установ, держсортодільниць та передового досвіду відомо, що одним із найважливіших інструментів збільшення врожайності, підвищення якості зерна та досягнення високого рівня рентабельності виробництва зерна пшениці озимої є сортозміна.

Селекційна практика свідчить, що новостворений сорт повинен не лише характеризуватися певними цінними господарськими ознаками, але й бути конкурентоспроможним, у порівнянні 3 іншими, за врожайністю та прибутковістю.

Тому нові досягнення селекційної науки потребують проходження етапу сортовипробування та виробничої перевірки в конкретних грунтовокліматичних умовах із наступним визначенням технологічної та економічної ефективності та формулюванням відповідних рекомендацій, що визначає новизну проведених наукових досліджень.
Аналіз останніх досліджень і публікацій, у яких започатковано розв'язання проблеми. Проблему розвитку виробництва зерна, зокрема пшениці, та інтенсифікації галузі досліджували такі вчені, як С. С. Бакай, В. І. Бойко, М. Г. Лобас, П. М. Рибалкін, В. С. Рибка [1], В. Ф. Сайко, А. І. Степанов, М. І. Щур та інші.

Встановлено, що зростання врожайності пшениці на 50-70\% за останні 50 років зумовлено використанням у виробництві високопродуктивних сортів. Однак генетично-селекційне поліпшення та створення сортів 3 подальшим підвищенням потенціалу продуктивності, стійкості до несприятливої дії абіотичних і біотичних чинників середовища $\epsilon$ надто важким завданням, що зумовлено надзвичайною складністю і комплексністю цих показників $[3,10]$.

Зниження рівня матеріально-технічного забезпечення вітчизняного зерновиробництва, порушення технологій вирощування пшениці, а також жорстокі флуктуації погодних умов потребують створення сортів інтенсивного типу з максимально визначеними адаптивними властивостями, високою якістю, морозо- й зимостійкістю, посухостійкістю, стійкістю до збудників хвороб, осипання зерна, витривалістю до різних відхилень у технології вирощування тощо $[3,4,7,11]$.

Нині до Державного реєстру сортів рослин, придатних для поширення в Україні, внесено близько 240 сортів пшениці м'якої озимої різних селекційних центрів, які відрізняються між собою господарськи цінними ознаками та адаптивними реакціями на умови вирощування.

3 одного боку, це дає зерновиробникам додаткові можливості добору кращого сортового матеріалу, з іншого - зростає імовірність придбання недостатньо перевіреного сорту в конкретній грунтово-кліматичній зоні, що призводить до значного ушкодження його в зимовий період, негативного впливу посух, ураження хворобами $\mathrm{i}$, як наслідок, - зниження врожайності, валових зборів та прибутковості зерновиробництва як на 


\section{ЕКОНОМІКА}

рівні окремого господарства, так і держави в цілому. У зв'язку з цим, як вважає низка дослідників $[5,9,12]$, у кожному регіоні необхідно проводити спеціальні досліди 3 новими сортами для визначення біологічних, морфологічних і господарсько-цінних ознак.

Це стосується сортів як вітчизняної, так і зарубіжної селекції, які активно залучають до вирощування. Зокрема, на особливу увагу заслуговують сорти далекого зарубіжжя, переважно німецької та канадської селекції, які останніми роками широко пропагують і впроваджують на полях нашої країни, зокрема в зоні Степу.

Метою дослідження $є$ обгрунтування шляхів підвищення ефективності виробництва зерна пшениці озимої в Північному Степу України на основі добору сортів 3 високим урожайним та адаптивним потенціалом.

Завдання - провести економічну оцінку багаторічних експериментальних даних сортовипробування пшениці озимої в грунтово-кліматичних умовах Північного Степу України та визначити перелік сортів, вирощування яких забезпечує найкращі показники врожайності та прибутковості.

Матеріали і методи досліджень. Інформаційною базою комплексного аналізу були результати експериментальних досліджень за 2009-2014 рр., що проводилися на Синельниківській селекційно-дослідній станції ДУ Інститут сільського господарства степової зони НААН.

Економічна оцінка проводилася на основі застосування загальноприйнятої методики, яка дає змогу оцінити варіант технології за рівнем урожайності, собівартості виробництва одиниці продукції, прибутковості гектара посівної площі та рівнем рентабельності.

Виробничі витрати розраховувалися на основі технологічних карт вирощування та діючих методичних рекомендацій $[1,2,6,8]$.

Ціни на зерно пшениці (без ПДВ) були диференційовані відповідно до якості отриманого зерна. Для розрахунку вартісних показників були прийняті ціни на виробничі ресурси та продукцію, що діяли в четвертому кварталі 2014 року.

Результати досліджень. Аналіз результатів сортовипробування показав, що протягом 20092014 рр. на ступінь реалізації сортового потенціалу та рівень прибутковості вирощування досліджуваних сортів великий вплив здійснювали погодні умови.

Вони за весь період досліджень були досить різними як за температурним режимом, так і за кількістю опадів під час вегетації пшениці озимої. Це дало можливість одержати достовірні дані щодо реакції рослин різних сортів на вплив абіотичних чинників протягом їхньої вегетації. Найсприятливіші погодні умови для вирощування пшениці озимої, що забезпечувало одержання високих показників врожайності, були в 2009, 2011, 2013, 2014 роках.

Несприятливий гідротермічний режим, що тривав більшу частину вегетаційного періоду озимини, спостерігався в 2010 та 2012 рр., що дало змогу всебічно перевірити сортовий склад на стійкість до посушливих умов в осінній і ранньовесняний період та низьких температур узимку (див. табл.).

Як свідчать результати економічного аналізу, вирощування кращих сортів пшениці озимої протягом 2009-2011 pр. забезпечувало отримання 31 гектару посіву 5,0-5,9 т високоякісного зерна та 5,9-7,7 тис. грн чистого доходу за рівня рентабельності 92,0-115,3\%.

Зокрема, у 2009 році серед 34-х досліджуваних сортів найвищу врожайність сформували сорти Подолянка (5,86 т/га), Антара (5,79 т/га), Смуглянка (5,71 т/га), Куяльник (5,62 т/га) і Ліст 25 (5,51 т/га) та забезпечили досягнення рівня рентабельності відповідно 115,3, 113,5, 111,4, 109,0 і 106,1 \% та отримання 6,95-7,69 тис. грн чистого доходу в розрахунку на 1 га посіву. Найгірші показники були отримані на ділянках де висівали сорти Пегасос, Акратос та Астрон: за врожайності 2,90-3,69 т/га було отримано 1,43-3,10 тис. грн чистого доходу в розрахунку на 1 га посіву та 0,25-0,52 грн - на 1 грн виробничих витрат.

У 2010 році формування найкращих показників продуктивності та прибутковості забезпечило вирощування сортів Смуглянка, Подяка, Кірія, Ліст 25 і Золотоколоса, коли за врожайності 5,00-5,62 т/га рівень собівартості 1 т зерна становив 1174-1278 грн, чистого доходу з 1 га - 5,877,18 тис. грн, а рівень рентабельності - 92,0$109,0 \%$.

Найнижчу врожайність сформували сорти Антара (4,07 т/га), Коханка (4,28 т/га) та Антонівка (4,29 т/га) за рівня рентабельності 64,3-71,1\%.

У 2011 році найкращі показники економічної ефективності сформувалися на ділянках, де вирощували сорти Шестопалівка, Золотоколоса, Кірія, Епоха одеська, Благодарка одеська: за врожайності 5,51-5,64 т/га 1 гривня витрачених коштів забезпечувала отримання 1,06-1,10 грн чистого доходу.

Сорти Варвік, Коханка та Актер були найменш конкурентоздатними за показників урожайності 4,52-4,78 т/га та рентабельності 78,1$85,7 \%$. 
EKOHOMIKA

Економічна ефективність вирощування різних сортів пшениці озимої по чорному пару

\begin{tabular}{|c|c|c|c|c|c|c|c|}
\hline \multirow{2}{*}{$\begin{array}{c}\text { № } \\
\text { у рей- } \\
\text { тингу }\end{array}$} & \multirow{2}{*}{$\begin{array}{c}\text { Найменування } \\
\text { сорту }\end{array}$} & \multirow{2}{*}{$\begin{array}{l}\text { Урожай- } \\
\text { ність, } \\
\text { т/га }\end{array}$} & \multirow{2}{*}{$\begin{array}{c}\text { Витрати } \\
\text { на } \\
1 \text { га, } \\
\text { грн }\end{array}$} & \multirow{2}{*}{$\begin{array}{c}\text { Собі- } \\
\text { вар- } \\
\text { тість } \\
1 \text { т, } \\
\text { грн }\end{array}$} & \multicolumn{2}{|c|}{$\begin{array}{c}\text { Чистий дохід у } \\
\text { розрахунку }\end{array}$} & \multirow{2}{*}{$\begin{array}{c}\text { Рівень } \\
\text { рент- } \\
\text { бель- } \\
\text { ності, } \\
\%\end{array}$} \\
\hline & & & & & $\begin{array}{c}\text { на } \\
1 \text { т, } \\
\text { грн } \\
\end{array}$ & $\begin{array}{c}\text { на } \\
1 \text { га, } \\
\text { грн }\end{array}$ & \\
\hline \multicolumn{8}{|c|}{2012 рік (несприятливий) } \\
\hline 1 & Богдана & 3,49 & 5874 & 1683 & 767 & 2676 & 45,6 \\
\hline 2 & Епоха одеська & 3,38 & 5837 & 1727 & 723 & 2444 & 41,9 \\
\hline 3 & Заграва одеська & 3,37 & 5834 & 1731 & 719 & 2422 & 41,5 \\
\hline 4 & Снігурка & 3,30 & 5811 & 1761 & 689 & 2274 & 39,1 \\
\hline 5 & Ліст 25 & 3,23 & 5787 & 1792 & 658 & 2126 & 36,7 \\
\hline 6 & Розкішна & 3,20 & 5777 & 1805 & 645 & 2063 & 35,7 \\
\hline 7 & Краснодарська 99 & 3,13 & 5754 & 1838 & 612 & 1915 & 33,3 \\
\hline 28 & Подяка & 1,27 & 5131 & 4040 & -1590 & -2020 & $-39,4$ \\
\hline 29 & Скарбниця & 1,12 & 5081 & 4536 & -2086 & -2337 & $-46,0$ \\
\hline 30 & Золотоколоса & 0,71 & 4944 & 6963 & -4513 & -3204 & $-64,8$ \\
\hline \multicolumn{8}{|c|}{2014 рік (сприятливий) } \\
\hline 1 & Ювілейна 100 & 7,52 & 7224 & 961 & 1489 & 11200 & 155,1 \\
\hline 2 & Краснодарська 99 & 7,31 & 7153 & 979 & 1471 & 10756 & 150,4 \\
\hline 3 & Золотоколоса & 7,29 & 7147 & 980 & 1470 & 10714 & 149,9 \\
\hline 4 & Епоха одеська & 7,26 & 7137 & 983 & 1467 & 10650 & 149,2 \\
\hline 5 & Таня (Оградська) & 7,24 & 7130 & 985 & 1465 & 10608 & 148,8 \\
\hline 6 & Заможність & 7,19 & 7113 & 989 & 1461 & 10502 & 147,6 \\
\hline 7 & Смуглянка & 7,17 & 7106 & 991 & 1459 & 10460 & 147,2 \\
\hline 49 & Донецька 48 & 4,98 & 6373 & 1280 & 1170 & 5828 & 91,4 \\
\hline 50 & $\mathrm{HC} 40$ & 4,86 & 6333 & 1303 & 1147 & 5574 & 88,0 \\
\hline 51 & Мирлена & 4,70 & 6279 & 1336 & 1114 & 5236 & 83,4 \\
\hline
\end{tabular}

Як показали одержані результати, серед досліджуваних сортів найбільш адаптованими до несприятливих умов вегетації (посушливі умови в осінній та весняно-літній періоди, низький температурний режим узимку) стали сорти Богдана, Епоха одеська, Заграва одеська, Снігурка, Ліст 25, Розкішна і Краснодарська 99, які навіть у надзвичайно складних умовах 2012 року сформували врожай зерна на рівні 3,13-3,49 т/га (див. табл.). Вирощування вищеперелічених сортів забезпечило беззбитковий рівень виробництва та рівень рентабельності від 33,3 до 45,6 \%. У 8-ми варіантах із 30-ти (3 рівнем урожайності 2,13 i нижче) були отримані збитки, які під час вирощування сортів Подяка, Скарбниця і Золотоколоса сягнули 2,02-3,20 тис. грн у розрахунку на 1 га та $0,39-0,65$ грн у розрахунку на 1 грн затрачених коштів.

Така ситуація пояснюється тим, що, як відомо, не всі сорти однаково реагують на ті чи інші умови вирощування, а тому й реалізація їх потенційної продуктивності відбувається по-різному. Високопродуктивні сорти виносять із грунту значно більшу кількість поживних речовин та вологи, а тому вимагають високої агротехніки, яка передбачає використання кращих попередників, дотримання оптимальних строків сівби, забезпечення необхідного фону живлення тощо. Якщо таких умов немає, то потенційно більш продуктивний сорт не тільки не дає збільшення врожаю, але й може поступитися за врожайністю менш продуктивному, але більш пластичному та невимогливому до умов вирощування сорту. Саме така ситуація відмічалася в 2012 році під час вирощування високопродуктивних сортів Подяка, Скарбниця, Золотоколоса та інших, які 3 об'єктивних причин розпочали зимівлю в нерозкущеному і далекому від оптимального стані. В результаті складних погодних умов протягом зимового періоду з відновленням весняної вегетації в них відмічалася значна втрата вегетативної маси, в порівнянні з іншими сортами, та більша частка рослин, що загинули, - в цілому від 20 до $60 \%$. Такі результати зимівлі в поєднанні з ранньовесняною посухою не дали змоги рослинам цих сортів відновити вегетативну масу і негатив- 


\section{EKOHOMIKA}

но вплинули на показники врожайності, які знаходилися на рівні 0,71-1,27 т/га і становили лише 20-40 \% від урожайності кращих сортів.

Найвищі показники ефективності виробництва зерна пшениці були отримані в найбільш врожайних 2013-му і, особливо, 2014-му роках. Так, у 2013 році максимальний рівень продуктивності забезпечив сорт Розкішна (7,01 т/га). Тут за рівня собівартості 1006 грн/т було досягнуто найвищого рівня рентабельності (143,5\%). Сорти Богдана, Епоха одеська, Благодарка одеська та Досконала характеризувалися дещо нижчою врожайністю (6,61-6,77 т/га), забезпечивши формування рентабельності на рівні 134,1-137,9 \%. Навіть у разі вирощування сортів 3 найменшими показниками продуктивності (Мирлена (5,49 т/га), Гордовита $(5,47$ т/га) і Нота $(5,32$ т/га)) рівень рентабельності був досить високий (100,9$105,5 \%$ ) і достатній для здійснення розширеного відтворення виробництва.

В 2014 році лідерами за показниками врожайності та рентабельності стали сорти Ювілейна 100 (7,52 т/га; 155,1%), Краснодарська 99 (7,31 т/га; $150,4 \%)$ і Золотоколоса (7,29 т/га; 149,9 \%). Понад 7 т зерна $з$ гектара посіву було отримано під час вирощування сортів Епоха одеська, Таня (Оградська), Заможність, Смуглянка i Bacca (7,17-7,26 т/га). У випадку собівартості 961-991 грн/т вирощування найкращих сортів забезпечило отримання 10,5-11,2 тис. грн чистого доходу 31 гектара.

У 2014 році розмах варіації врожайності серед досліджуваних сортів був більшим, ніж у попередньому році. Водночас вирощування найменш продуктивних сортів зі врожайністю 4,70-4,98 т/га також було достатньо прибутковим, забезпечуючи отримання 83-91 коп. чистого доходу в розрахунку на одну затрачену гривню.

За результатами проведених досліджень встановлено, що всі сорти зарубіжної селекції, які вивчали в дослідах, поступалися за врожайністю сортам вітчизняної селекції і характеризувалися нижчою зимо- та посухостійкістю, а також були більш пізньостиглими, через що зазнавали інтенсивного впливу високих температур під час фор-

\section{БІБЛІОГРАФІЯ}

1. Економіка виробництва зерна в зоні Степу України (з основами організації і технології виробництва) : монографія / [Черенков А. В., Рибка В. С., Шевченко М. С. та ін.] ; за ред. А. В. Черенкова і В. С. Рибки. - Дніпропетровськ : Нова ідеологія, 2015. - 300 с.

2. Економічний довідник аграрника / [Дробот В. I., Зуб Г. І., Кононенко М. П. та ін.] ; за ред. Ю. Я. Лу- мування й дозрівання зерна.

Беручи до уваги мінливість температурних показників, фактичний сортовий склад пшениці озимої та спираючись на результати багаторічних досліджень ДУ Інституту сільського господарства степової зони НААН та інших наукових установ, було сформульовано рекомендації щодо вдосконалення сортової структури 3 урахуванням адаптивного потенціалу та рівня зимостійкості сортів. Раціональний сортовий склад у більшості областей зони Степу має становити 17-19 сортів із відхиленням як у бік зменшення до 1417, так і збільшення їх до 19-21 залежно від розмірів озимого клину.

В умовах конкретних агроформувань доцільно висівати 3-5 сортів, які відрізняються між собою за біологічними та господарськими ознаками: зимостійкістю, скоростиглістю, посухостійкістю, різною реакцією на попередники, строки сівби, добрива тощо. Використання низькозимостійких сортів $є$ недоцільним.

\section{Висновки:}

1) 3 метою раціонального використання сортового складу та щорічного одержання сталих урожаїв пшениці озимої рекомендується висівати в господарствах 3-5 сортів із різними біологічними та господарськими ознаками.

2) Здійснення правильного добору сортового складу має враховувати не лише врожайний, але й адаптивний потенціал сучасних технологічно орієнтованих сортів, їх стійкість до стресових умов, вилягання, обсипання зерна під час дозрівання та проростання зерна в колосі. Водночас мають переважати сильні та цінні сорти пшениці вітчизняної селекції.

3) Для зерновиробників степової зони на сьогодні кращими сортами пшениці озимої за комплексною оцінкою є Смуглянка, Епоха одеська, Кірія, Золотоколоса, Благодарка одеська, Богдана, Ліст 25, Розкішна.

Програмою подальших досліджень передбачається коригування списку сортів на основі отриманих результатів 3 постановкою на сортовипробування нових досягнень селекції пшениці озимої.

зана, П. Т. Саблука. - К. : Преса України, 2003. C. 294-309.

3. Корчмарський B. C. Створення вихідного матеріалу та сортів пшениці м'якої озимої на підвищену адаптивність для Лісостепу України : дис. на здобуття наук. ступеня д.с.-Г.н. : 06.01.05. / Корчмарський Валентин Сергійович. - Дніпропетровськ, 2013. - 332 с. 


\section{ЕКОНОМІКА}

4. Литвиненко M. А. Реалізація генетичного потенціалу. Проблеми продуктивності та якості зерна сучасних сортів пшениці озимої / М. А. Литвиненко // Насінництво. - 2010. - №6 (90). - С. 1-6.

5. Напрями підвищення якості зерна пшениці озимої м'якої в Лісостепу України / [Корчмарський В. С., Колючий В. Т., Блохін М. І. та ін.] // Посібник укр. хлібороба. - К., 2009. - С. 24-31.

6 . Науково-практичний довідник по обгрунтуванню поелементних нормативів трудових, грошово-матеріальних та енергетичних витрат на виробництво зернових культур / [Черенков А. В., Рибка В. С., Кулик А. О. та ін.] ; за ред. А. В. Черенкова і В. С. Рибки. - Дніпропетровськ : Нова ідеологія, 2014. - 180 с.

7. Нові сорти озимої м'якої пшениці інтенсивного типу для степової та лісостепової зон, особливості їх агротехніки та насінництва / [Лифенко С. П., Ериняк М. І., Нарган Т. П., Наконечний М. Ю.] // Посібник укр. хлібороба. - К., 2010. - С. 243-245.

8. Нормативна собівартість та ціни на сільськогосподарську продукцію. Ціноутворення та нормативні витрати в сільському господарстві (тео- рія, методологія, практика) : [за ред. П. Т. Саблука, Ю. Ф. Мельника, М. В. Зубця, В. Я. МесельВеселяка]. - К. : ННЦ ІАЕ, 2008. - Т. 2. - С. 8-38.

9. Орлюк А. П. Сортова політика у вирощуванні високих урожаїв якісного зерна озимої м'якої пшениці на півдні України : міжвід. темат. наук. зб. / А. П. Орлюк // Зрошуване землеробство. - Херсон : Айлант, 2007. - Вип. 48. - С. 9-16.

11. Пшеница: история, морфология, биология, селекция / [Шелепов В. А., Чебаков Н. П., Вергунов В. А., Корчмарский В. С.] ; под ред. В. В. Шелепова. - Мироновка, 2009. - 573 с.

12. Рӧ̈к M. В. Системне наукове забезпечення розвитку сучасної технології селекційного процесу / М. В. Роїк // Вісник Українського товариства генетиків і селекціонерів. - К., 2003. - №1. C. 17-36.

13. Сайко В. Ф. Технологія вирощування високоякісного зерна пшениці озимої в Лісостепу та Поліссі України / В. Ф. Сайко, І. М. Свидинюк, Л. М. Кононюк // Посібник укр. хлібороба. 2009. - С. 45-48. 